\title{
Impacts of a two degree increase in temperature on pasture growth in the Northern Tablelands of New South Wales
}

\author{
R. Powell ${ }^{a}$, C. Edwards ${ }^{b}$, R.S. Hegarty ${ }^{c}$ and $\underline{\text { M.J. McPhee }}^{d}$ \\ ${ }^{a}$ School of Environmental and Rural Science, University of New England, Armidale NSW, 2351 \\ ${ }^{b}$ NSW Department of Primary Industries, Ring Road Armidale NSW 2351 \\ ${ }^{c}$ Department of Animal Science, University of New England. Armidale, NSW 2351 \\ ${ }^{d}$ NSW Department of Primary Industries, Trevenna Rd, Armidale, NSW 2351 \\ Email: malcolm.mcphee@industry.nsw.gov.au
}

\begin{abstract}
Sheep production is the major contributor to the agricultural economy of the Northern Tablelands of New South Wales. In 1996/97 \$109.1 million was derived from sheep production. There is a pressing need for agricultural industries to reduce their carbon footprint and global warming is a major concern. This study has simulated a sheep production system of a 36 ha research station called 'Trevenna' located at the University of New England, Armidale ( $\left.30^{\circ} 30^{\prime} \mathrm{S} 151^{\circ} 40^{\prime} \mathrm{E}\right)$. The 'Trevenna' site has been set up as a demonstration site for producers, advisers, students, and researchers to gain insight into how to estimate and measure livestock enteric methane emissions.

The Sustainable Grazing Systems (SGS) model was used to simulate, over 50 years, pasture growth on the 'Trevenna' demonstration site. Simulations contrasted the impacts of a $2^{\circ} \mathrm{C}$ change in temperature on herbage mass $(\mathrm{t} / \mathrm{ha})$ and pasture growth rate $(\mathrm{kg} \mathrm{C} / \mathrm{ha} /$ day). A validation check indicated that the predicted values from $1^{\text {st }}$ Sep 2010 to $30^{\text {th }}$ March 2011 fell within $10 \%$ of the observed values.

There was no effect of the $2^{\circ} \mathrm{C}$ increase in temperature on green herbage mass $(\mathrm{P}>0.05)$ but a significant difference for dead herbage mass and pasture growth rate $(\mathrm{P}<0.05)$. The increase in dead herbage mass is discussed.

A significant effect of temperature on botanical composition $(\mathrm{P}<0.05)$ was found with an increase in $\mathrm{C} 4$ native grasses (e.g. kangaroo grass, red grass, and wire grass) at the expense of other pasture species present in the sward. The impact of a $2^{\circ} \mathrm{C}$ increase in temperature reduced the number of frosts (defined as mornings below $2^{\circ} \mathrm{C}$ ) and number of severe frosts (defined as mornings below $0^{\circ} \mathrm{C}$ ).

In conclusion, a $2^{\circ} \mathrm{C}$ increase in temperature on the Northern Tablelands of New South Wales can be expected to increase pasture growth, particularly of $\mathrm{C} 4$ species, so supporting an increase in herbage mass.
\end{abstract}

Keywords: Climate change, decision support system, herbage mass, senescence 


\section{INTRODUCTION}

A large proportion of the Northern Tablelands in New South Wales is grazed for sheep production, particularly fine-wool flocks. Within these grazing systems the majority of pastures are a combination of introduced, improved, and native species. The total value of agricultural production on the Northern Tablelands in 1996/97 was estimated at \$217.8 million: 50.1\% derived from sheep production; $41.7 \%$ derived from wool production; and 8.4\% from prime lamb production (Alford et al., 2003). Herbage mass (kg $\mathrm{DM} / \mathrm{ha}$ ) is a key determinate of stocking rate that an enterprise can carry and therefore the amount of animal product that can be generated.

Climate variability is a major issue confronting agriculture. There is a pressing need for agricultural industries to reduce their carbon footprint. Agricultural emissions (methane $\left(\mathrm{CH}_{4}\right)$ and nitrous oxide $\left(\mathrm{N}_{2} \mathrm{O}\right)$ ) comprise $16 \%$ of Australia's total emissions, and livestock emissions (enteric fermentation and manure management) contribute $69 \%$ of agricultural emissions (Department of Climate Change and Energy Efficiency 2010). Therefore, it is of great interest to determine the effects of a change in temperature on pasture production. Several studies have estimated the effects of an increase in minimum and maximum temperature on pasture production (Thornley and Cannell, 1997, Cullen et al., 2009). However, no specific studies on the Northern Tablelands have been undertaken. This study has simulated a sheep production system on a 36 ha research station called 'Trevenna' located at the University of New England, Armidale $\left(30^{\circ} 30^{\prime} \mathrm{S} 151^{\circ} 40^{\prime} \mathrm{E}\right)$ using the Sustainable Grazing Systems (SGS) model (Johnson et al., 2003).

The objective of this study was to evaluate the impact of a $2^{\circ} \mathrm{C}$ increase in temperature on pasture growth within a sheep production enterprise on the Northern Tablelands of New South Wales, Australia.

\section{MATERIAL AND METHODS}

\subsection{Trevenna Demonstration Site}

The Trevenna demonstration site, located at the University of New England, on the Northern Tablelands of New South Wales ( $30^{\circ} 30^{\prime} \mathrm{S} 151^{\circ} 40^{\prime}$ E) comprises 36 ha, split between high and low productivity systems. An overview of the site has been described by McPhee et al. (2010). The 'Trevenna' demonstration site has been subdivided into 18 paddocks: 9 allocated for high productivity improved pastures and 9 allocated for low productivity predominately native pastures. The paddocks averaged 2 ha ranging from 1.8-2.2 ha. Each landscape was classified into classes (A, B and C) based on an EM38 electromagnetic induction survey. Within each class 3 paddocks were allocated. There were 6 flocks: 3 high and 3 low productivity flocks. Flocks were rotationally grazed through 3 paddocks so that each flock had a turn in each landscape class (A, $\mathrm{B}$ and $\mathrm{C}$ ). The high productivity flocks were stocked at $6.7 \mathrm{DSE} / \mathrm{ha}$ (i.e. 32 ewes and single lambs rotationally grazing $6 \mathrm{ha}$ ) and the low productivity flocks were stocked at $3.7 \mathrm{DSE} / \mathrm{ha}$ (i.e. 16 ewes and single lambs rotationally grazing $6 \mathrm{ha})$.

\subsection{Data Collection}

Data has been collected to feed into decision support systems to estimate the amount of methane produced. The data collected will also be used as inputs to greenhouse inventory calculators (e.g. FarmGas (2010)). The measurements taken include:

- Soil moisture measurements taken on a weekly basis. Measurements were taken using a Diviner moisture probe (Sentek Technologies, Sydney). The moisture probe used was a capacitance probe that uses the electrical conductivity of a soil to determine the moisture content (Thomas, 1966). The access tubes were located within one paddock of each land class within each landscape. The measurements were taken in $10 \mathrm{~cm}$ increments to a depth of $50 \mathrm{~cm}$.

- Herbage mass measurements were undertaken on a monthly basis when the animals were rotated between paddocks. Pre and post grazing measurements were undertaken using the median quadrat technique (Bell, 2007). A scan of each quadrat was taken using a Crop Circle (Holland Scientific equipment model ACS210) scanner. The data from the observed values and the scans have been used to develop a Normalised Difference Vegetation Index (Trotter et al., 2010) 
- Botanical compositions were conducted 4 times per year, once per season using the method described by Tothill et al. (1992).

- Lambs were weighed on a monthly basis, when mobs were rotated between paddocks. These monthly lamb weights were recorded using their National Livestock Identification System Radio Frequency Identification tag. Condition score, fleece weights, and quality of fleece were also recorded.

\subsection{Simulation}

The SGS model (Johnson, 2003) was used to perform a 50 year simulation of high and low productivity sheep production systems. The soil parameters in the SGS model were stabilised over a 10 year period from 1960 to 1970 before a full 50 year simulation from 1960-2010 was conducted. Each of the 2 landscapes was modelled separately for 3 flocks on each landscape that was rotational grazed across 3 paddocks using the information recorded from the Trevenna site (McPhee at al., 2010). Data used from the site included: herbage mass, species composition and stocking density. Table 1 reports the input values used in the simulations.

Within the SGS model supplementary feeding was established to begin feeding when ewes dropped below $40 \mathrm{~kg}$ liveweight. Below this weight forage and concentrate supplements were fed at a rate calculated by the model to produce liveweight gains. The implementation of supplementary feeding within the SGS model occurred when the pasture quantity and quality was insufficient to maintain liveweight. Actual on-farm supplementary feeding was supplied to ewes as per the UNE animal ethics requirements.

The simulation was run using historical weather data for Armidale Airport Automatic Weather Station, NSW $\left(30.5^{\circ} \mathrm{S}\right.$ $\left.151.6^{\circ} \mathrm{E}\right)(\mathrm{BOM}, 2011)$. The initial pasture availability at the beginning of September 2010 was used as the starting herbage mass 1st September, 1960. The botanical

Table 1. Input values used in the SGS model for 'Trevenna'

\begin{tabular}{|l|l|}
\hline Variable & Value \\
\hline Farm & 16 low productivity 32 high productivity \\
\hline Number of ewes & 36 ha \\
\hline Farm Area & 9 high productivity, 9 low productivity \\
\hline Paddocks & $1.8-2.2$ ha \\
\hline Paddock Areas & 30 days each paddock \\
\hline Rotation & None \\
\hline Irrigation & \\
\hline Soil & $1.3 \mathrm{~g} / \mathrm{cm}^{3}$ \\
\hline Bulk Density & $48 \%$ of Volume \\
\hline Saturated point & $35 \%$ of Volume \\
\hline Field Capacity & $16 \%$ of Volume \\
\hline Permanent Wilting point & \\
\hline Fertiliser & May each year \\
\hline Application & $70^{2} \mathrm{~kg} / \mathrm{ha}$ Urea \\
\hline Nitrogen- Urea & $20^{1} \mathrm{~kg} / \mathrm{ha}$ \\
\hline Phosphorous & $25^{2} \mathrm{~kg} / \mathrm{ha}$ \\
\hline Sulphur & \multicolumn{2}{|l|}{} \\
\hline Animal & 3 high productivity 3 low productivity \\
\hline Animal growth curve & $47 \mathrm{~kg}$ \\
\hline Flocks & $43.0,44.7,46.3,44.1,45.3,44.5 \mathrm{~kg}$ \\
\hline Mature liveweight of ewe & $35 \mathrm{~kg}$ \\
\hline Starting liveweight of ewe \\
flocks 1-6
\end{tabular}

${ }^{1} .10 \mathrm{~kg} / \mathrm{ha}$ yearly after first application

2. no application after first year

3. flocks allocated to landscape classes as described in McPhee et al., (2010)

September was used as inputs to the SGS model. The soil nutrients and water values were used from the normalised values obtained in the 10 year scenario (1960-1970). Following the simulation the data produced was processed using the Post Processor 3 program. The program specifically developed as part of the SGS project summarising the model output (Anon., 2011). The data was processed to provide monthly summaries of all factors. Following the historical simulation the weather data was combined with the CSIRO Mk 3.5 Model following the A2, medium emissions scenario, using the climate downscaling software tool WeatherMaker (Gordon et al., 2010). The daily weather output file from this program was used as the observed weather values for the SGS model where the minimum and maximum temperatures were increased by $2^{\circ} \mathrm{C}$. These weather values were then used with the same initial conditions for the historical weather data (baseline) scenario (i.e. 2 simulations were conducted: (1) baseline; and (2) a $2^{\circ} \mathrm{C}$ increase in minimum and maximum temperatures of the baseline year). 
To ensure accuracy of the model the baseline simulation was run from the 1st September 2010 through to the $31^{\text {st }}$ of March 2011. This enabled the predicted values from the simulation to be compared to the observed values of herbage mass, botanical composition, soil moisture and lamb weights.

\subsection{Statistical Analysis}

The results from the simulation were analysed using the statistical package R (R Development Core Team, 2005). An analysis of variance was performed to compare the differences in herbage mass and pasture growth with a $2^{\circ} \mathrm{C}$ increase in temperature. No statistical interpretation between landscapes can be made because only 1 year of the experiment has been conducted (i.e. not a replicated study). This study only evaluates the difference between the baseline and the $2^{\circ} \mathrm{C}$ increase in temperature.

\section{RESULTS}

Following the 50 year simulation the observed versus predicted values of herbage mass, botanical composition, soil moisture, and lamb weights from $1^{\text {st }}$ Sep 2010 to $30^{\text {th }}$ March 2011 were found to be consistent and fell within $10 \%$ of the observed values, giving confidence in interpretation of modelled impacts on pasture growth over the 50 year time frame

The 50 year simulation showed no statistical difference $(\mathrm{P}>0.05)$ between the baseline and $2^{\circ} \mathrm{C}$ increase in temperature simulations for green herbage mass or total herbage mass, but a significant difference $(\mathrm{P}<0.05)$ for dead herbage mass (Table 1). Nevertheless the $2^{\circ} \mathrm{C}$ increase did increase total herbage mass compared to the baseline climate data (Table 1).

Table 1. Mean and standard deviation (SD), over 50 year simulation, green, dead and total herbage mass $(\mathrm{tDM} / \mathrm{ha})$ and mean gross positive growth rate $^{1}$ ( $\mathrm{kg}$ carbon/ha/day) across sheep enterprises grazing low or high productivity landscapes, in the presence of historical temperatures (Baseline) and $2^{\circ} \mathrm{C}$ increase in temperature

\begin{tabular}{|c|c|c|c|c|c|c|c|c|c|}
\hline Landscape & $\begin{array}{l}\text { Climate } \\
\text { Scenario }\end{array}$ & $\begin{array}{l}\text { Green } \\
\text { Herbage } \\
\text { Mass } \\
\text { (tDM/ha) }\end{array}$ & SD & $\begin{array}{l}\text { Dead } \\
\text { Herbage } \\
\text { Mass } \\
\text { (tDM/ha) }\end{array}$ & SD & $\begin{array}{l}\text { Total } \\
\text { Herbage } \\
\text { Mass } \\
\text { (tDM/ha) }\end{array}$ & SD & $\begin{array}{l}\text { Gross Positive } \\
\text { Growth Rate }^{1} \\
\text { (kg C/ha/day) }\end{array}$ & SD \\
\hline Low & Baseline & 1.19 & 0.54 & $1.20^{\mathrm{a}}$ & 0.47 & 2.39 & 0.97 & $18.50^{\mathrm{a}}$ & 5.49 \\
\hline Low & $2^{\mathrm{O}}$ increase & 1.26 & 0.58 & $1.37^{\mathrm{b}}$ & 0.57 & 2.63 & 1.03 & $20.56^{b}$ & 7.00 \\
\hline High & Baseline & 1.64 & 0.52 & $0.92^{\mathrm{a}}$ & 0.32 & 2.28 & 0.75 & $33.01^{\mathrm{a}}$ & 11.91 \\
\hline High & $2^{\mathrm{O}}$ increase & 1.57 & 0.67 & $1.17^{b}$ & 0.41 & 2.73 & 1.10 & $35.56^{\mathrm{b}}$ & 13.26 \\
\hline
\end{tabular}

Differing superscripts in same column are significantly different $(\mathrm{P}<0.05)$

${ }^{1}$ gross positive growth rate $=$ daily gross photosynthesis + remobilised carbon from senescent tissue (Johnson, 2008)

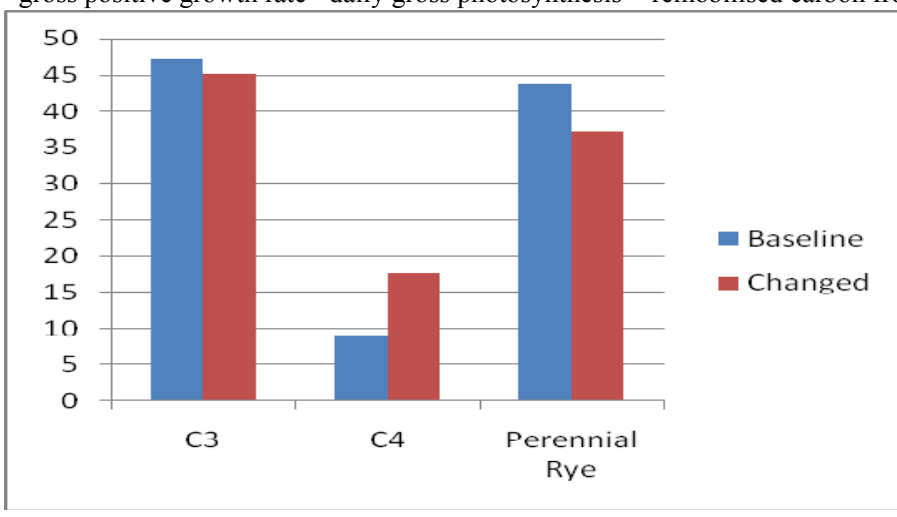

Figure 1. Predicted species abundance (\%) across 50 year simulation of the high productivity landscape between Baseline (historical temperatures) and $2{ }^{\circ} \mathrm{C}$ increase in temnerature (Chanoed)
A lower amount of supplement was fed during the changed climate scenario, as a result of the greater herbage mass. In both the baseline and changed scenarios the concentrate intake was lower in the high productivity landscape, compared to the low productivity landscape.

In terms of the botanical composition the high productivity landscape (Figure 1) was statistically significant $(\mathrm{P}<0.05)$ for all pasture species (C3 (e.g., weeping grass and common wheatgrass), C4 (e.g. kangaroo grass, red grass, and wire grass), White Clover, Perennial Rye) between the baseline and changed scenarios. However 
for the low productivity landscape (Figure 2) only C4 and Perennial Rye were statistically significant $(\mathrm{P}<$ $0.05)$ between the baseline and changed scenarios.

\section{DISCUSSION}

The higher gross positive growth rate (daily gross photosynthesis + remobilised carbon from senescent tissue) that occurred in the high productivity landscape compared to the low productivity landscape in both climate scenarios may be attributed to the botanical composition. Robinson and Archer (1988) showed that introduced species have a higher growth rate compared to native species. The low productivity landscape class consists predominantly of native pasture species, while the high productivity landscape consists of

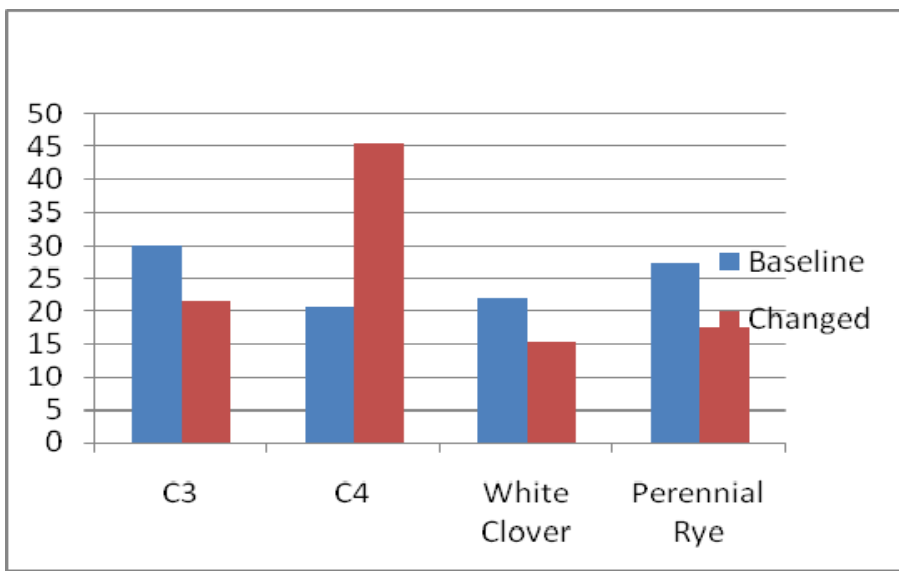

Figure 2. Predicted species abundance (\%) across 50 year simulation of the low productivity landscape between Baseline (historical temperatures) and $2^{\circ} \mathrm{C}$ increase in temperature (Changed). introduced perennial species (McPhee et al., 2010). The high productivity landscape is more responsive to additional fertility and to water, exhibiting a faster growth rate. The increase in growth rate as a result of a $2^{\circ} \mathrm{C}$ increase is due to the warmer temperatures experienced and lower frost damage to plants.

The herbage mass present is a function of the growth rate and number of animals grazing. The results from this study show that a difference in pasture growth rate occurred when the minimum and maximum temperatures were increased by $2^{\circ} \mathrm{C}$ and consequently a change in herbage mass. As the stocking rates were unchanged, the pasture consumption was unchanged. A net increase in herbage mass occurred because the stocking rate

and consequently intake did not change.

As the temperature increased the number of frosts, (defined as mornings below $2^{\circ} \mathrm{C}$ ) was reduced. The number of severe frosts, (defined as mornings below $0^{\circ} \mathrm{C}$ ) also declined. The lower number of mild and severe frosts therefore increased the growth rate as the low temperature effects are reduced (Ludlow, 1980). This effect is more pronounced in the Spring and Autumn, as the mean minimum temperature during the Northern Tablelands winter is $0.95^{\circ} \mathrm{C}(\mathrm{BOM}, 2011)$. An increase in $2^{\circ} \mathrm{C}$ results in the temperature remaining below the lower critical temperature of $\mathrm{C} 4$ grasses $\left(4^{\circ} \mathrm{C}\right)$ (Ivory and Whiteman, 1978). Hence, even in the warmer climate, cold temperatures remain a restriction to pasture growth. A reduction in pasture growth rate on the low productivity landscape may have occurred due to the high proportion of native $\mathrm{C} 4$ grasses (Figure 2). A mean increase of $2^{\circ} \mathrm{C}$ will increase the mean minimum temperature to 2.95 degrees. This is above the lower critical temperature of many temperate introduced species, allowing increased pasture growth rate on the high productivity landscape.

The small increase in green herbage mass on the low productivity scenario in response to an increase in temperature may have occurred because of the reduction in plant death associated with reduction in frosts. This is contrasted with the decrease in green herbage mass that occurs in the high productivity landscape as a result of the $2^{\circ} \mathrm{C}$ increase (Figure 1). This could have occurred on the low productivity landscape as a result of increased pasture intake and a decrease supplementary feed intake. Gurung et al. (1994) showed that sheep will graze green herbage in preference to dead.

The results from this study show that the increased proportion of $\mathrm{C} 4$ grasses that were found to be present as the temperature increased may be attributed to the temperature increase favouring their growth and therefore increasing the $\mathrm{C} 4$ herbage mass present in the sward. The magnitude of the increase was similar in both landscapes, approximately doubling in prevalence as the temperature increased. 
In conclusion a $2^{\circ} \mathrm{C}$ increase in minimum and maximum temperatures significantly increased pasture growth rate and the species abundance of the $\mathrm{C} 4$ grasses present in the sward; with this resulting in part from reduced frost impact on these species in warmer conditions. As stocking rate was not changed in the model, the extra pasture growth at the warmer temperature led to an increased accumulated mass of dead pasture.

\section{ACKNOWLEDGEMENTS}

The authors thank Meat \& Livestock Australia and the Australian Government Climate Change Research Program for funding this project and a Cicerone scholarship for an honours student to undertake this project.

\section{REFERENCES}

Alford, A., Griffith,. G.and Davies, L. (2003). Livestock Farming Systems in the Northern Tablelands of NSW: An Economic Analysis, Orange, NSW, NSW Agriculture.

Anon. (2011). http://www.wfsat.landfood.unimelb.edu.au/Tools.htm

Bell, A. (2007). Measuring herbage mass- the median quarat technique, NSW Department of Primary Industries.

BOM (2011). Climate Data, Armidale Airport AWS.

Cullen, B. R., Johnson, I. R., Eckard, R. J., Lodge, G. M., Walker, R. G., Rawnsley, R. P. \& McCaskill, M. R. (2009). Climate change effects on pasture systems in south-eastern Australia. Crop and Pasture Science, 60, 933-942.

Department of Climate Change and Energy Efficiency (2010), http://www.climatechange.gov.au/government/initiatives/cprs/who-affected/agriculture/agriculturalemissions.aspx

Gordon, H., O’Farrell, S., Collier, M., Dix, M., Rotstayn, L., Kowalczyk, E., Hirst, T. \& Watterson, I. (2010). The CSIRO Mk3.5 Climate Model, Melbourne, Australia.

Gurung, N. K., Jallow, O. A., McGregor, B. A., Watson, M. J., McIlroy, B. K. \& Holmes, J. H. G. (1994). Complementary selection and intake of annual pastures by sheep and goats. Small Ruminant Research, 14, 185-192.

FarmGas (2010). Farm Gas Calculator, Australian Farm Institute, Surry Hills, NSW 2010 http://www.farminstitute.org.au/calculators/farm-gas-calculator.

Ivory, D. \& Whiteman, P. (1978). Effect of Temperature on Growth of Five Subtropical Grasses. I. Effect of Day and Night Temperature on Growth and Morphological Development. Functional Plant Biology, $5,131-148$.

Johnson, I. R., Lodge, G.M. and White, R.E (2003). The Sustainable Grazing Systems Pasture Model: description, philosophy and application to the SGS National Experiment. Australian Journal of Experimental Agriculture, 43, 711-728.

Johnson, I.R. (2008). Pasture Growth. http://www.imj.com.au/consultancy/wfsat/Pasture.pdf

Ludlow, M. (1980). Stress physiology of tropical pasture species. Tropical Grasslands Journal, 14, $163-145$.

McPhee, M. J., Edwards, C., Meckiff, J., Baillie, N., Schnider, D. A., Arnott, P., Cowie, A., Savage D., Lamb, D. W., Guppy, C. N., McCorkell, B. and Hegarty, R. (2010). Estimating on-farm methane emissions for sheep prduction on the Norther Tablelands: establishment of demonstration site. Australian Farm Business Management, 7, 85-94.

R development core team (2005). R: A Language and Environment for Statistical Computing. Vienna, Austria.

Robinson, G. and Archer, K. (1988). Agronomic potential of native grass species on the Northern Tablelands of New South Wales. I. Growth and herbage production. Australian Journal of Agricultural Research, 39, 415-423.

Thomas, A. M. (1966). In situ measurement of moisture in soil and similar substances by 'fringe' capacitance. Journal of Scientific Instruments, 43, 21.

Thornley J. H. M. and Cannell, M. G. R. (1997). Temperate Grassland Responses to Climate Change: and Analysis using the Hurley Pasture Model. Annals of Botany, 80, 205-221.

Tothill, J. C. (1992). BOTANAL : a comprehensive sampling procedure for estimating pasture yield and composition. In, Field sampling / J.C. Tothill, J.N.G. Hargreaves, R.M. Jones \& C.K. McDonald, Brisbane :, CSIRO, Division of Tropical Crops and Pastures.

Trotter, M. G., Lamb, D. W., Donald, G. E. and Schneider, D. A. (2010). Evaluating an active optical sensor for quantifying and mapping green herbage mass and growth in a perennial grass pasture. Crop and Pasture Science, 61, 389-398. 